\title{
Rekognisie (herinnering) as meganisme vir die identifisering van betekenis van die liturgiese elemente in die erediens
}

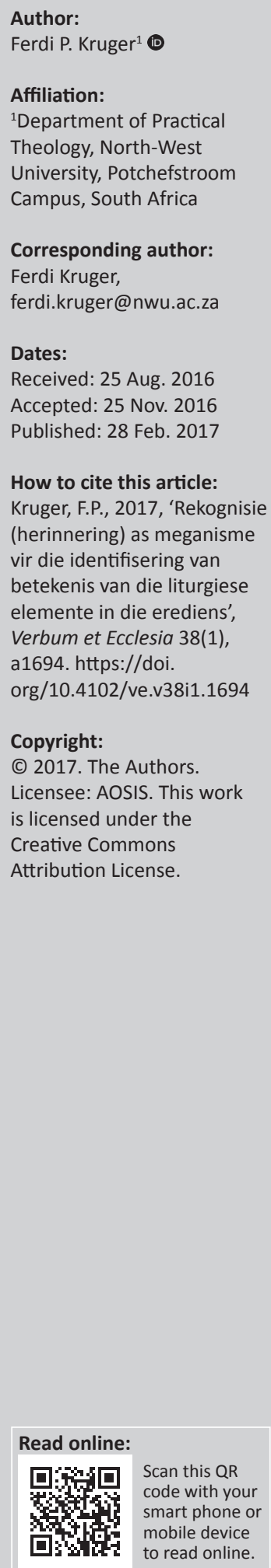

Recognition (remembrance) as mechanism in identifying the meaning of the liturgical elements in a worship service. It is indicated in research within the field of liturgical studies that participants, during worship services and while participating in all the liturgical elements, have to contend with the process of recognition. The author is conducting an investigation into the role of recognition in identifying the value of the liturgical moments during worship services, with a closer illustration of the introit and also the humbling and reconciliation service. The following research problem is stated for this research, namely: What impact has recognition (remembrance) on the meaning of elements familiar to the participants in identifying the value of the worship service? This investigation will be done from a practicaltheological vantage point with the integration of important principles. Recognition has to do with the remembering (re-collection) of familiar things, events and words during the worship service. The essence of remembering is to bring new meaning to and understanding of the liturgical elements. An intradisciplinary discourse with the fields of Church History and Cognitive Science will also take place. The concept of anamnesis will further be normatively examined from the angle of 1 Corinthians 11:25, also Hebrews 10:3, and the importance of anamnesis (remembering) will be brought to the fore. The moments of the introit, as well as moments of the humiliation and reconciliation service, are regarded as important for the dynamic and organic flow of the rest of the worship service. Practical-theological perspectives will be drawn from this exposition in order to indicate that it is important to reflect on the value of recognition in the act of liturgy.

Intradisciplinary and/or interdisciplinary implications: This article is undertaken from a practical-theological vantage point in order to highlight the importance of the concept of recognition for further research within the field of liturgics. In this article a discourse between Practical Theology, Church History and Cognitive Psychology is undertaken. Important aspects were indicated and also the importance of the concept of anamnesis. The importance of understanding and remembrance were also indicated. The concept of anamnesis was discussed according to 1 Corinthians 11:25 and Hebrews 10:3. Finally, practical-theological perspectives were offered in which the importance of recognition for certain liturgical elements was indicated. This particular study could possibly contribute towards better insight into the influence of remembrance in liturgy and also enable participants to understand the essence of liturgy during worship services.

\section{Inleiding}

Eredienste wat mense se lewens verander, vereis 'n liturgie wat deelnemers se oortuigings en gesindhede deur middel van kragtige herinnerings beïnvloed (Stetter 2013:381). Deelnemers aan die erediens behoort te verstaan wat die betekenis is van liturgiese elemente tydens die erediens sodat die liturgie na afloop van die erediens voortgesit kan word in die liturgie van die lewe (Kvanvig 2008:493). Strawn en Brown (2013) sluit op die volgende wyse hierby aan, naamlik:

What is done by participants in the worship service is of greater importance as what is said and done by the worship leader. We do gather in order for each whole person and the gathered church to be formed through the context of worship. (p. 12)

Cilliers (2004:41) benader hierdie aangeleentheid vanuit die belangrikheid van God se teenwoordigheid in die erediens. Sy navorsing fokus in die besonder op hoe deelnemers aan die erediens die teenwoordigheid van Christus kan herken. Die vertrekpunt word in dié artikel gestel dat die erediens wel bedoel is om betekenisvol te wees. Die betekenisvolle handeling van die 
liturgie bring 'n ontologiese gerigtheid voort waarin die betekenis van die liturgie en die bestaan van die mens met mekaar in verband gebring word (Hughes 2003:11). Liturgie en die konkrete omstandighede van mense in hul lewens staan in 'n onlosmaaklike verband met mekaar. Mense word in aansluiting by bogenoemde aspek deur die erediens in hulle 'daar-wees' (bestaan) geraak. Die erediens behoort rekening te hou met die rekognisie vir die realiteit van elke deelnemer aan die erediens van die lewe (Louw 2015:14). Alhoewel die begrip rekognisie moontlik vatbaar is vir ander interpretasies, sal die belangrikheid van hierdie begrip verder in die artikel uitgelig word. Voortspruitend vanuit die betekenis van die begrip rekognisie behels dit dat herkenning (rekognisie) as 'n meganisme funksioneer om die betekenis van die grootheid van God tydens die liturgiese elemente onder die erediens te identifiseer.

'At the heart of all worship, is the act of remembrance' (Atkins 2004:25). Nullens (2015:83) benadruk in sy navorsing oor die kerk in 'n sekulêre omgewing dat die kerk 'n herinneringsen 'n verhalende geloofsgemeenskap is. Volgens Haarman (2004:271) dui liturgiese handelinge geensins op 'n nagedagtenis (in memoriam) van iets of iemand wat passief totdieverledebehoortnie,maarwelop'n 'Beziehungsgeschehen'. Om liturgies gevorm te kan word, is dit onvermydelik dat gelowiges deur erediensviering herinner word aan God se groot en magtige dade (Nullens 2015:83). Die veronderstelling in dié artikel is dat die betekenis van die begrip 'rememiri' [herinnering] inhou dinge vanuit die verlede, hede en toekoms en word dit met 'n eiesoortige dinamiek van vitaliteit gevul.

Die liturgiese krag van herinnering (ook genoem rekognisie) bring 'n eskatologiese spanningsveld voort (Haarman 2004:279). Die spanningsveld hou rekening daarmee dat deelnemers aan die erediens moontlik op eensydige wyse besig kan wees met die dinge van die verlede en nie die betekenis van die erediens vir die hede en vir die toekoms begryp nie. Kruger (2016:8) beskryf die belangrikheid van verstaan as die proses van kognisie tydens die erediens en bedoel hiermee dat die deelnemers probeer om sin te maak uit alles wat beleef en waargeneem word. Liturgie het wel betekenis vir die deelnemers hieraan, maar die betekenis hiervan moet elke keer opnuut ervaar word langs die weg van die proses van rekognisie (herinnering). Sodoende funksioneer die prosesse van kognisie en rekognisie in 'n ellips en kan hulle moontlik as twee sentrale handelinge van die erediens beskou word. Ford (2005:300) sluit hierby aan en wys daarop dat herinnering ' $n$ kragtige handeling is wat in die modus van die teenwoordige tyd gedoen word ('der Christus praesens').

Gesien in die lig van bogenoemde is die begrip rekognisie wel van belang in nadenke oor wat onder die erediens moet geskied. Die volgende voorlopige definisie van wat onder rekognisie verstaan word, word reeds nou gebied, naamlik: rekognisie behels die herkenning van dinge waarmee mense vertroud is (Wood \& Wood 1999:199). Rekognisie hou rekening met die herkenning of die identifisering van inligting waarmee persone reeds voorheen gemoeid was (bekende dinge). Eysenck en Keane (2010:260) verdeel op hulle beurt rekognisie tussen die prosesse van herinnering en van familiariteit. Herinnering geskied op die basis van inligting of detail wat herroep word, terwyl familiariteit (vertroudheid) geskied op die basis van die oproep van sake op grond van die vertroudheid hiermee. Vanuit hierdie voorlopige omlyning van die begrip rekognisie word twee fokuspunte alreeds voorlopig geïdentifiseer, naamlik rekognisie as herinnering, asook rekognisie as die vertroudheid met bekende dinge.

Die navorsingsvraag vir hierdie artikel kan op die volgende wyse geformuleer word, naamlik: Watter impak het rekognisie as die herinnering aan en vertroudheid met die elemente van die liturgie op deelnemers om die betekenis van die erediens te identifiseer?

In die metodologiese aanpak sal die navorsing op voetspoor van Dingemans (1996:62) in drie fases geskied, naamlik:

- Die analiserende of ontledende beskrywing van die prakties teologiese situasie.

- Die ondersoek na normatiewe gesigspunte.

- Die ontwikkeling van veranderingstrategieë op grond van die beskrywing van normatiewe uitgangspunte.

Tydens hierdie eerste fase van die navorsing word (1) voorbeelde van navorsing en refleksie rondom die probleemveld in oënskou geneem, (2) die bestaande teologiese invalshoeke en grondslae vir rekognisie in ag geneem en (3) waarnemings gemaak vanuit die Kerkgeskiedenis en Kognitiewe Psigologie oor rekognisie in die dinamika van gelowiges se deelname aan die erediens. In die tweede fase van die navorsing word 'n ondersoek gedoen na normatiewe gesigspunte waaruit die belangrikheid van anamnese (herinnering) benadruk word. In die derde fase sal liturgies praktykteoretiese perspektiewe gebied word op die belangrikheid van die element van rekognisie vir deelnemers aan die erediens se betrokkenheid by die impak van die erediens.

\section{Deskriptiewe beskrywing van navorsing in die Liturgiek oor die problematiese praksis}

Liturgiek het te make met handelinge tydens die erediens wat die erediens, asook die diens van die lewe, ten nouste raak. Dié onderafdeling bied kwalitatiewe refleksie oor navorsing wat die afgelope 12 jaar onderneem is om die noodsaak van dié veld van ondersoek nog duideliker te omlyn (vgl. ook Osmer 2008:32).

\section{Navorsing oor die performatiewe aard van liturgie wat betekenis vir deelnemers ontsluit}

Routhier (2015:7) beklemtoon eredienste wat vir deelnemers aan die erediens moet sin maak. Hiervolgens is betekenisvolle eredienste van kardinale belang. Bogenoemde outeur bring sodoende die buitelyne van verstaan (kognisie) vir die erediens na vore. Vir Immink (2014:39) is die erediens 
performatief van aard. Deelnemers aan die liturgie raak so betrokke by die erediens dat hulle God se verlossingswerk in Christus as lewende realiteit ervaar. Vir Immink behels die deelname van gelowiges aan die erediens dat die herinnering aan wat Christus gedoen het 'n uitwerking in die hede sal openbaar. Smith (2013:4) bied 'n uitgebreide uiteensetting oor die vormende krag van liturgie, aangesien mense volgens hom 'liturgical animals' is. Bogenoemde outeur is egter besorg oor die gebrekkige begrip vir die vormende (kreatiewe) krag wat liturgie besit. Daarom is dit belangrik dat gelowiges die logika, asook die praktykgerigtheid, van die erediens sal begryp.

Vos (2009:297) besin oor gelowiges wat na die erediens kom, maar swaar dra aan Godsbeelde. Die probleem hiermee is dat liturgie vanaf kleintyd moontlik aandadig kon gewees het aan 'n verskraalde Godsbeeld of moontlik die indruk (beeld) kon geskep het dat God afwesig is in die liturgie. Liturgie kan moontlik in, sowel die positiewe sin van die woord as in die negatiewe sin van die woord, 'n uitwerking hê.

\section{Die spanningsveld van die eskatologie (tussen tye) in die erediens}

Bradshaw (2009:93) fokus in navorsing op die teenwoordigheid van Christus tydens die nagmaalviering en wys op die misterieuse verhouding tussen die viering van die nagmaal en die teenwoordigheid van God hierin deur die werking van die Heilige Gees. Die gebeure wat was, word sodoende weer lewend gemaak en in die hede gekonkretiseer. Berger en Spinks (2009:31) beklemtoon in hul navorsing die werking van die Heilige Gees wat God se toekoms na die hede bring sodat die verlede, hede en toekoms op misterieuse wyse verbind word. Die eskatologiese spanning verbonde aan erediensviering staan vir hulle voorop. Mitchell (2008:1) dui aan dat selfs abstrakte konsepte tydens die erediens met sowel die kognitiewe aspekte, asook die gedagte van onthou (rekognisie), te make het. Ongelukkig word bogenoemde navorsing meer toegespits op die nagmaal, terwyl ander elemente van die liturgie nie hieraan verbind word nie.

\section{Navorsing oor die teenwoordigheid van God (praesentia realis) in die erediens}

Bria (2006:5) beklemtoon dit dat liturgie baie meer as 'n blote herdenking is van wat God eenmaal lank gelede gedoen het. Liturgie is eerder die realisering van wat God doen in elke nuwe konteks. Bria (2006:11) verduidelik verder dat die vertikale dimensie van liturgie gegrond is in die rekognisie van die transendensie van God, maar ook in die feit dat Hy in die midde van sy volk wil woon (immanensie). Vir Kubicki (2006:62) is die liturgie die versameling van tekens waarin betekenis opgesluit is. Hy toon verder aan dat kognisie, sowel as rekognisie, betrekking het op die liturgie omdat albei oor die verstaan gaan, maar ook om herkenning. Bogenoemde outeur beskou herkenning as die proses van integrasie. Kubicki (2006:63) het die liturgie verder as die kollektiewe geheue van die kerk beskryf. Hiermee word aangedui dat geheue meer as die blote onthou van kennis of onthoubare dinge is. Die geheue van die kerk het te make met die begrip (kognisie) van wie die gelowige werklik is, waar elke mens vandaan kom en waarheen hy onderweg is. Bogenoemde outeur is besorg oor wat hy bestempel as die geheueverlies tydens die erediens, terwyl die opdrag om te onthou, sentraal staan. Pecklers (2003:6) toon aan dat liturgie te make het met die krag van rituele, asook met nieverbale kommunikasie waartydens die betekenis in die doen van die handelinge opnuut weer ontdek word.

Vanuit bogenoemde beskrywing van navorsing oor die afgelope 12 jaar, blyk dit dat die essensie van die begrip rekognisie en selfs die begrip rekognisie self bekend is, maar dat die omvang van rekognisie, asook die betekenis hiervan vir die vakgebied Liturgiek moontlik nog nie heeltemal voldoende verken is nie.

\section{Die analiserende of ontledende beskrywing van die begrip rekognisie}

In hierdie onderafdeling word aansluiting gevind by die inter- en intradissiplinêre benadering van die maatskaplike wetenskappe (Cartledge 2003:15; Pieterse 2001:13). Hierdie onderafdeling is van belang, nie alleen omdat dit in die metodologie gevisualiseer is nie, maar wel om te verhoed dat oorvereenvoudiging van die praksis geskied. Vir hierdie doeleindes sal dialoog gevoer word met die dissiplines van die Kerkgeskiedenis, asook die Kognitiewe Psigologie. In die gesprek met die insigte vanuit die Kerkgeskiedenis sal volstaan word met 'n uiteensetting oor Aurelius Augustinus (354-430 n.C. ), 'n teoloog uit Afrika, wie se denke selfs die Christelike tradisie in die geskiedenis in vele opsigte beïnvloed het.

\section{Analiserende perspektiewe vanuit die vakgebied van die Kerkgeskiedenis: Besinning oor Augustinus se beskouing van herinnering of herkenning}

In hierdie onderafdeling word nadere aandag gegee aan Augustinus se geskrif, Belydenisse (Confessiones), juis omdat hierdie prominente figuur integraal besin het oor die rol van herinnering. Venter, Symington en Van Wyk (2007:3) toon aan dat Augustinus se belydenisse begin vanaf die uitgangspunt dat die mens gemaak is om God te loof. Geen mens kan volgens Augustinus rus ervaar alvorens hulle hul rus in God vind en Hom loof nie. Volgens Venter et al. (2007:264-362) is die volgende aspekte opvallend in Augustinus se denke oor die mens se vermoë om te kan herken, naamlik:

- Die mens se sintuie is funksioneel om God se grootheid in die heelal te herken. Alles wat mense deur hulle sintuie waarneem, moet met die waarheid in hul binneste vergelyk word. Hierdie vermoë om deur middel van sintuie te kan waarneem, word deur God aan die mens geskenk (Venter et al. 2007:263-264).

- Die mense se geheue is soos 'n ruim paleis of 'n voorraadkamer waarin ontelbare beelde byeengebring is. Die sintuie van die mens het baie dinge hierheen vervoer 
(Venter et al. 2007:267). In die mens se geheue is gedagtes gestoor waardeur persepsies oor dinge en persone vergroot, verklein of aangepas word. Indien mense in hul geheue delf, word die eis ingedien dat alles wat die mens wil onthou, na vore moet kom. Sekere persepsies kom onmiddellik na vore, terwyl daar langer na ander gesoek moet word. Sekere indrukke storm as't ware op 'n mens af, terwyl ander herinneringe eintlik gesoek moet word (Venter et al. 2007:268). Die mens se geheue bewaar die herinneringe en hulle word selfs volgens soorte gerangskik. Alles wat die sintuie waarneem, kom as beelde (vgl. die uiteensetting oor skemas) in die mens se geheue in.

- In die geheime stoorkamer van die geheue onthou mense wat met hulle gebeur het of selfs wat hulle by ander mense geleer het. Mense maak hier vir hulself uit wat hulle kan glo en wat in ooreenstemming met hulle eie ervaring is (Venter et al. 2007:269). Mense is selfs in staat om herinneringe te pas in die groter prent van die verlede; hulle kan oorweeg wat hulle in die toekoms sal doen en verwag en kan selfs oor al dié dinge nadink asof hulle regtig teenwoordig is (Venter et al. 2007:270).

- Die krag van die geheue is groot en omvangryk sodat geen mens dit kan meet nie (Venter et al. 2007:271). In die mens se geheue word kennis geberg. Om te dink oor sake behels om stof vanuit die geheue bymekaar te bring of om aan te hou om waarnemings bymekaar te bring (Venter et al. 2007:274). Die mens is bevoorreg om feite te kan onthou, selfs die argumente wat teen hulle ingebring is. Mense is in staat om te kan onderskei tussen wat waar en wat vals is. Mense kan herinneringe dus willekeurig oproep (Chambliss 1989:238).

- Die geheue bevat die mens se gevoelens oor persone en gebeurtenisse (Venter et al. 2007:275). Die mens se geheue word deur Augustinus die gees se maag genoem en daarin is die soet sowel as die bitter van die lewe opgeneem. Blydskap en hartseer is soos kos wat soet en bitter smaak. Gevoelens word uit die mens se geheue na vore gebring, amper soos beeste wat herkou.

- Die mens moet die kragtige geheue verbysteek om God te vind (Venter et al. 2007:281). Tog kan geen mens God vind indien God self nie in die geheue is nie. ' $n$ Mens kan alles wat onthou word, bloot herken (Venter et al. 2007:283). So kragtig is die geheue van die mens dat daar selfs besef word dat iets soos 'n naam of insident vergeet is. Vergeet is op sigself ' $n$ manier van onthou. By die aanhoor van 'n wenk, herken die mens se geheue weer die detail (Venter et al. 2007:284). Juis daarom moet mense God soek sodat hulle innerlik kan lewe. Niemand sou ware geluk kon herken het indien die betekenis en konsep hiervan nie reeds in hulle geheue is nie.

- Augustinus staan verwonderd voor die feit dat vandat hy God ken, God in sy geheue is (Venter et al. 2007:290). Volgens Augustinus vind die mens God in sy geheue, elke keer wanneer hy of sy oor God dink (Venter et al. 2007:291). God is in alle fasette van die geheue aanwesig, aangesien Hy die God en Eienaar van die mens se gees is (Venter et al. 2007:291). Die mens se geheue is funksioneel om God te kan herken (Pakpahan 2012:15). In verband hiermee maak Augustinus 'n insiggewende opmerking, naamlik dat die mens se geheue ten diepste met die herinnering aan God self te make het.

- Augustinus se siening oor herkenning kan nie van sy mening oor tyd geskei word nie. Hy huldig die mening dat dit nie korrek is om van drie tye, naamlik die verlede, hede en toekoms te praat nie (Venter et al. 2007:348). Hy verkies die volgende onderskeid, naamlik: 'n hede van dinge wat verby is, 'n hede van dinge wat nou gebeur en 'n hede van dinge wat nog moet kom. Die hede van dinge wat verby is, word deur Augustinus beskryf as die mens se herinnering (Venter et al. 2007:348). Die hede van dinge wat gebeur, word deur hom as die mens se waarneming beskryf, terwyl die hede van dinge wat nog moet kom, die mens se verwagting genoem kan word. Vanuit hierdie beredenering wil dit voorkom asof Augustinus erns maak met die wete dat die mens as't ware tussen tye leef. Daarom kan tyd slegs vanuit die toekoms kom, deur die hede beweeg en in die verlede uitloop (Venter et al. 2007:349). Anders gestel, dit behels dat tyd ontstaan het uit iets wat nog nie bestaan nie; dit beweeg dan deur die hede wat nie tydsduur het nie en loop uit in die dinge wat nie meer bestaan nie. Alles wat in mense se lewens geskied, laat indrukke agter van dinge wat in die verlede wegraak (Venter et al. 2007:358). Die mens se lewe word gekenmerk deur drie handelinge wat met die begrip tyd verband hou, naamlik verwag, opmerk en onthou. Die verwagting aan wat nog moet kom en die herinnering aan die verlede dien as 'n kragbron vir die hier en nou (Venter et al. 2007:360).

\section{Analiserende perspektiewe vanuit die Kognitiewe Psigologie oor rekognisie}

\section{Terminologiese verwarring}

Vanuit die Kognitiewe Psigologie wil dit voorkom asof outeurs se sieninge uiteenlopend is oor presies waar rekognisie in terme van die kognitiewe denkproses geplaas moet word. Sekere outeurs plaas rekognisie binne die veld van die menslike geheue en wil rekognisie begryp as die aksie van die geheue (Bergh \& Theron 2006:143). Ander outeurs soos Schwartz en De la Rey (2004:241) vereenselwig rekognisie met onthou. Louw \& Edwards (1998:283) plaas rekognisie onder die herwinningsvermoë van inligting waaroor mense beskik. Atkins (2004:15) verstaan op sy beurt rekognisie as die proses van onthou of die herkenning van iets waarmee mense vertroud is. Wood en Wood (1999:590) plaas herkenning (rekognisie) ook binne die raamwerk van die mens se geheue. Bogenoemde outeurs toon ooreenstemming in dié opsig dat rekognisie wel gekoppel word aan die kognitiewe funksionering van mense, maar toon ook aan dat daar drie maniere bestaan waaraan geheue gemeet kan word, naamlik: die herroeping van feite, die herkenning van voorwerpe of gebeure, asook die proses om inligting of aksies opnuut weer aan te leer. In die proses van rekognisie herken mense daarom ervarings of persone wat aan hulle bekend is.

\section{Nadere omlyning van die begrip rekognisie}

Eysenck en Keane (2010:260) beweeg nader aan die onderskeid ten opsigte van rekognisie wat die outeur graag in hierdie 
artikel wil volg, naamlik rekognisie as 'n aksie van die geheue wat herinnering, sowel as familiariteit (bekendheid) insluit. Herinnering (rekognisie) is 'n proses waartydens mense op grond van 'n kontekstuele raamwerk sekere inligting oproep, terwyl bekendheid te make het met die herkenning van dinge wat waargeneem word. Wood en Wood (1999:199) sluit aan by die gedagte van bekendheid en onderstreep die gedagte dat rekognisie die teenoorgestelde van die blote herroep van feite is. Mense is in staat om voorwerpe of sake te herken op grond van die feit dat iets aan hulle bekend is of omdat hulle reeds voorheen hiermee kontak gemaak het. Daarom word voorkeur aan die nuanses van herinnering en identifisering gegee indien daar oor rekognisie besin word. Dit gaan met ander woorde nie bloot oor feite wat herroep word nie, maar wel oor mense se identifisering daarmee. Rekognisie (herinnering) het te make met die poging van mense om voorwerpe, woorde, boodskappe en mense te identifiseer as bekend en iets waarmee hulle vantevore reeds te make gehad het (Wood \& Wood 1999:199). Atkins (2004:13) toon aan dat die verlede met die hulp van rekognisie die hede word en dat rekognisie verder bepalend is vir mense se toekomstige optrede. Rekognisie is sodoende ' $n$ proses wat mense in staat stel om herinneringe uit die verlede ' $n$ lewende werklikheid te maak en is verder instrumenteel in die motivering ten opsigte van toekomstige optrede. Dit blyk dus dat wat mense onthou en herroep, 'n uitwerking het op hoedanig hulle die realiteit interpreteer. Die verband tussen rekognisie en taal is verder insiggewend in dié opsig dat alles wat mense in woorde omskep, makliker is om op te roep (Atkins 2004:21). Woorde het 'n snelleruitwerking op mense se geheue en kan met die strepieskode op produkte wat aangekoop word, vergelyk word. Woorde roep herinneringe op.

\section{Rekognisie en die funksionering van skemas}

Mense verstaan en interpreteer die samelewing waarbinne hulle leef aan die hand van skemas. Hierdie skemas kan aangeleer word uit direkte ervaring, maar ook via die vertelling van ander mense (Fiske 2004:166). 'n Skema kan beskryf word as 'n dinamiese betekenisraamwerk (Louw \& Edwards 1998:273). Bergh en Theron (2006:128) voeg by dat skemas handel oor interaksie met iets of iemand met wie daar onlangs 'n ontmoeting plaasgevind het. Die inligting oor die saak of persoon met wie daar kontak was, word georganiseer in 'n samehangende beeld. Dit word meermale beskryf as 'n poging waarin mense of sake gekategoriseer word of anders gestel, voorsien word van 'n etiket (Weiten 1995:246). Daarom skep skemas in mense se lewens bepaalde verwagtinge van wat moontlik verwag kan word (Eysenck \& Keane 2010:401). Skemas het 'n belangrike funksie in mense se lewens, aangesien dit kognitiewe strukture is wat inligting bewaar en organiseer (Baron \& Byrne 1994:121). Sodoende dra die bestaan van skemas ook daartoe by dat mense bereid is om aan sekere dinge en aan sekere aspekte meer aandag te gee as aan ander. Skemas en vorige ervarings het ' $n$ onlosmaaklike band met mekaar. Sodoende beïnloed die funksionering van skemas selfs die tipe dinge wat mense onthou (Eysenck \& Keane 2010:401).
Die funksionering van skemas in mense se lewens hou verband met vorige leerervarings sowel as die betekenis wat gebeure vir mense inhou (Schwartz et al. 2004:241). Mense se vorige leerervarings wat in skemas georganiseer word, vorm sodoende die struktuur of raamwerk waarbinne nuwe inligting aangeleer word. Vanuit bogenoemde uiteensetting blyk dit dat indien rekognisie te make het met vorige leerervarings van mense, dit begryplik is dat mense se rekognisie van sake en van mense sal verskil. Die rekognisie van een mens verskil van dié van 'n ander mens juis omdat hulle leerervarings en ontmoetings van mekaar verskil. Rekognisie (herinnering) is die konstruktiewe proses waartydens inligting wat bewaar word binne die raamwerk van relevante skemas na vore gebring word. Dit is dus 'n herinnering aan ervarings wat reeds deurleef en deurdink is.

\section{Rekognisie en konteks}

In die Kognitiewe Psigologie is daar al besin oor die vraag of herinneringe werklik akkuraat kan wees. Volgens Schwartz en De la Rey (2004:241) is die argument te wyte daaraan dat herinnering en geheue in die verlede dikwels op eensydige wyse verwring is deur die vergelyking tussen die menslike brein en 'n rekenaar. In die Kognitiewe Psigologie het die begrip vir die konteks waarbinne mense se geheue funksioneer toenemend aandag begin ontvang (vgl. Kruger 2015:6; Fiske 2004:156; Weiten 1995:247). Dit is veral die navorsing wat Neisser in hierdie verband gedoen het wat op die voorgrond tree. Neisser het bekendheid verwerf vir sy ekologiese benadering tot die veld van herinnering (Schwartz \& De la Rey 2004:241). Die ekologiese benadering tot die funksionering van die proses van rekognisie behels dat sekere kontekste sterker herinnerings as ander kontekste voortbring. Herinnering hou verband met die beskrywing van konteksafhanklikheid (Bergh \& Theron 2006:130). Die konteks waarbinne 'n ontmoeting of die aanleer van kennis plaasgevind het, dien meermale as 'n leidraad in die proses van rekognisie.

Die konteks waarna verwys word, behels meer as net die fisieke omgewing waarbinne mense hulle bevind. Die sosiokulturele omgewing waarbinne mense funksioneer, is ook belangrik in die proses van onthou en herinnering (Schwartz \& De la Rey 2004:242). Hierdie beklemtoning behels dat mense se herinnering moontlik selfs 'n produk kan wees van hulle konteks. Dit bring mee dat mense se belewing van die alledaagse konteks ' $n$ invloed uitoefen op die funksionering van herinnering. Die leidrade wat mense se konteks bied, is daarom 'n raamwerk waarbinne herinnering geskied.

\section{Normatiewe perspektiewe op die begrip herinnering (rekognisie)}

Aan die begin is aangedui dat daar op die voetspoor van Dingemans (1996:96) se metodologiese insig normatiewe rigtingwysers aangedui sal word. Die begrip rekognisie hou verband met die begrip anamnese en juis daarom word dit van belang geag om verder hieraan aandag te gee. In hierdie onderafdeling sal die begrip anamnese (herinnering) soos dit 
in 1 Korintiërs 11:25, asook in Hebreërs 10:3 gebruik word, nader belig word. In dié artikel word volstaan met die ontleding van die begrip $\alpha v \alpha \mu \nu \eta \sigma ı \varsigma$, aangesien hierdie begrip binne die onmiddellike verband van die liturgie en van die erediens gebruik word.

\section{Normatiewe perspektiewe vanuit 1 Korintiërs 11:25}

Ciampa en Rosner (2010:542) toon aan dat die betekenis van 'n erediens opgesluit is in herinne-ring. Horsley (1998:158)

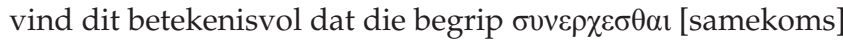
vyf kere in 1 Korintiërs 11 (verse 17, 18, 20, 33, asook 34) gebruik word en nog twee kere in hoofstuk 14 (verse 23 en

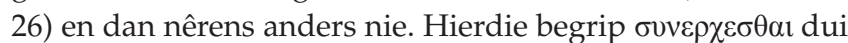
op mense wat saamkom om 'n societas [gemeenskap] te vorm (McShane 1999:132). Pakpahan (2012:115) benadruk die feit dat die begrip herinnering (anamnese) dikwels in die Bybel gebruik word binne die konteks van 'n ontmoeting met God. Deur die ontmoeting met God word die aktiewe God van die verlede in die hede in herinnering geroep om sodoende nuwe betekenis vir die hede en toekoms te skep. Herinnering (rekognisie) is 'n daad waarin die verlede nuut gemaak word (Pakpahan 2012:118). Die begrip $\alpha v \alpha \mu \nu \eta \sigma ı \varsigma$ is 'n aktiewe daad van betekenisgewing aan persone en sake waarmee mense reeds vertroud is, maar dit word sodanig gedoen dat die persoon of saak in die hier en nou teenwoordig gestel word (Pakpahan 2012:139). Wanneer gelowiges byvoorbeeld die nagmaal vier, word Christus se offer en oorwinning 'n lewende realiteit vir gelowiges in dié opsig dat wat gevier word, weer herleef word. Louw en Nida (1993:348) beklemtoon in hulle uiteensetting dat die begrip $\alpha v \alpha \mu v \eta \sigma ı$ daarop dui dat iets die herinnering ontlok. Sodoende word die gedagte beklemtoon dat 'n bepaalde aspek so belangrik is dat dit veroorsaak dat die betekenis hiervan vanuit die geheue opgeroep word (Louw \& Nida 1993:347). Daarom sou die nuanse relevant wees van herinnering as 'n proses waarin mense genoodsaak word om opnuut weer oor iets na te dink.

Ciampa en Rosner (2010:543) verduidelik verder hoedat die apostel Paulus met die verskillende aspekte van herinnering omgaan, naamlik waardering vir die feit dat die gemeente hom onthou, maar dat hy ontevrede is oor die wyse waarop gelowiges Christus se teenwoordigheid in die nagmaalviering in herinnering bring. Deur hul optrede in hul samekomste en die wyse waarop hulle gedenk, word eintlik meer kwaad gedoen as goed. Groenewald (1980:145) benadruk die letterlike betekenis van die woorde, naamlik dat hulle samekomste die slegte bewerkstellig en nie die goeie nie. Die begrip saamkom dui op die uitdrukking wat destyds algemeen bekend was, naamlik saamkom tot dieselfde (McShane 1999:133). By hierdie byeenkomste waar gelowiges saamgekom het om hul eenheid in Christus te vier, het gemeenskap met mekaar 'n sentrale rol gespeel (Groenewald 1980:147). Liturgie het juis ten doel om mee te werk aan die bevestiging van ordelike verhoudinge onderling, wat insluit die verhouding met God, asook die onderlinge gemeenskap. Daarom moet die liturgie van die nagmaalviering gelowiges lei tot die ervaring of die smaak van die geloof (Moore-Keish
2008:37). Haarman (2004:276) beskryf herinnering as 'n geestelike oriëntering wat plaasvind tydens die erediens. In hierdie oriëntering word die werklikheid van Christus se teenwoordigheid deur die werking van die Gees bewerk.

Die nagmaal is bedoel om Christus te herdenk, maar deur die wanpraktyke van onverdraagsaamheid en liefdeloosheid in Korinthe het 'n reeks splintermaaltye geskied (Ciampa \& Rosner 2010:552). Die gelowiges moes opnuut besef dat die nagmaalviering alles met Christus te make het. Hulle moes leer om reg en met waardering te gedenk. Die wyse waarop die brood genuttig word en die wyn gedrink word, moes 'n herinnering of selfs 'n herlewing wees van die wyse waarop Christus die brood en wyn op die vooraand van sy kruisiging met sy dissipels gedeel het (Horsley 1998:157). Paulus deel die oproep om te gedenk op sodanige wyse dat hulle opnuut weer die gebeure van die instelling van die nagmaal in Christus se teenwoordigheid kon herleef (Ciampa \& Rosner 2010:551). Hierdie gedenkaksie behels meer as die herroeping van die gebeure op die vooraand van Christus se kruisiging. Hierdie gedenkaksie het veral twee momente ontsluit, naamlik nadenke (meditasie) en die verkondiging van die inhoud van alles wat gedenk moes word (Groenewald 1980:149). Dit blyk dat herinnering die moment van hoorbare en sigbare Woordverkondiging bevorder. Ciampa en Rosner (2010:553) toon aan dat die herinnering van deelnemers aan die maaltyd rekognisie eis van wat hulle reeds in Christus ontvang het. Hierdie rekognisie moet noodgedwonge ook 'n veranderde fokus op die gemeente se onderlinge verhoudinge (gemeenskap) voortbring. Vanuit bogenoemde bespreking het geblyk dat rekognisie (anamnese), met Christus se teenwoordigheid as anker, as stimulus van diepgaande transformasie dien en onderlinge verhoudinge versterk. Die wyse waarop Christus se teenwoordigheid tydens die erediens deur herinnering 'n werklikheid word, bevorder die wyse waarop liturgie verder beoefen word in die liturgie van die lewe. Verder het dit ook geblyk dat herinnering ten doel het om die verlede as ' $n$ lewende realiteit te identifiseer. Rekognisie as die kragtige identifisering van waardevolle aspekte waarmee mense vertroud is, is sodoende die dinamo van krag en hoop vir die toekoms. Herinnering (anamnese) is derhalwe dinamies en aktief in sowel die werking as die uitwerking hiervan.

\section{Normatiewe perspektiewe op die begrip $\alpha v \alpha \mu v \eta \sigma \iota s$ [gedenk of herinner] in Hebreërs 10:3}

Hebreërs 10:3 begin met die begrip $\alpha \lambda \lambda \alpha$ [maar]. Ellingworth (1993:495) is van mening dat die voegwoord ' $n$ kontras beskryf tussen 'n onwerklike situasie en die realiteit. Kistemaker (1984:273) sluit hierby aan en toon aan dat die kontras noodsaaklik is om aan te toon dat die offers van die ou bedeling in alle opsigte te kort geskied het. Die offers in die ou bedeling was nie in staat gewees om mense se sonde weg te neem nie. Die offers wat deur die hoëpriester gebring is, was op sigself ' $n$ herinnering aan die sonde van die mens (Bruce 1990:237). Hierdie herinnering is veel meer as om 'n gedagte op te roep en iets te onthou. Flanigan (1997:197) toon 
aan dat die herinnering op die 'yom kippur' [versoendag een maal per jaar] selfs die gedagte inhou van 'n verbintenis wat in die gedagtes van gelowiges moes plaasvind tussen wat nou die geval is en wat verlede jaar die geval sou gewees het. So moes die herinnering hulle ook daaraan herinner dat hulle dit die volgende jaar weer sal ervaar.

Tydens hierdie versoendag is gelowiges voortdurend herinner aan hulle sonde en moes gelowiges die sonde in hulle eie lewens oproep (Flanigan 1997:197). Ellingworth (1993:495) maak die stelling dat die begrip herinnering nie alleen betrekking het op die werk van Christus nie, maar ook daarop dui dat die $\mathrm{Ou}$ Testamentiese offers, benewens die feit dat gelowiges van God moes onthou, hulle eie sonde in herinnering moes bring. Hy toon verder aan dat die begrip nie in die psigologiese sin van die woord verstaan moet word nie, maar wel in terme van 'n aksie wat gevolge inhou. Bruce (1990:237) verduidelik dat die kontras opgesluit is in die herinnering aan die Ou Testamentiese offers en die herinnering aan die offer van Christus; wanneer deelnemers aan die erediens Christus se offer in herinnering roep, dit vanuit die perspektief van verlossing en vergifnis plaasvind. Evans (1985:173) beskou die krag van herinnering as iets wat opgesluit lê daarin om ervarings uit die verlede weer in die gedagtegang na vore te bring.

Teenoor hierdie anamnese (herinnering) aan die sonde wat jaar ná jaar moes geskied, staan die kontras, naamlik dat Christus vir eens en altyd die volmaakte offer vir sy volgelinge gebring het. Juis hierdie besef bring Long (1997:102) by kritiese refleksie uit oor prediking wat meer effektief oor die sonde kan handel as wat dit genade in sy volle omvang verkondig. Sodoende word elke erediens volgens bogenoemde outeur opnuut weer 'n herinnering aan die yom kippur. Teenoor hierdie beklemtoning, plaas Long die besef van die offer wat Christus eens en vir altyd gebring het. Calvyn neem die saak nog 'n stap verder en benadruk die besef dat die boodskap van versoening nie die daaglikse anamnese (herinnering) aan sonde totaal en al wegneem nie (Johnstone 1994:133). Herinnering (anamnese) sou sodoende inhou dat gelowiges op daaglikse basis moet dink aan hul sondes wat in Christus vergewe is. Daarom sou die gepaste anamnese of herinnering vir Calvyn iets wees wat tot belydenis van skuld aanleiding gee en tot die behoefte aan verlossing (Johnstone 1994:134). $\mathrm{Du}$ Toit (2002:160) verbind die uiteenlopende verklarings deur die verbintenis te vind in die begrip skaduwee. Die offers van die ou bedeling was 'n skaduwee van die dinge wat sou kom. Dit het met ander woorde 'n skaduwee bevat van die toekomstige dinge wat sou kom. Die anamnese (herinnering) aan sonde kan nie geskei word van die herinnering aan Christus se verdienste nie (Du Toit 2002:161). Dit is juis die bedoeling van Christus se volmaakte offer gewees, naamlik dat gelowiges op grond hiervan altyd met vrymoedigheid na die troon van genade kan gaan.

Vanuit bogenoemde beredenering het geblyk dat herinnering (anamnese) vanuit die hoek gesien van die $\mathrm{Ou}$ en Nuwe Testament, ' $n$ begrip is wat dieselfde funksie het as die twee kante van dieselfde muntstuk. Herinnering aan die sonde lei noodwendig tot die verwagting van wat Christus gedoen het, terwyl die herinnering aan die offer van Christus tegelyk ook die besef en belydenis van sonde na vore roep.

\section{Samevatting}

Die uiteensetting van 1 Korintiërs 11:25, sowel as Hebreërs 10:3, het na vore gebring dat herinnering (anamnese) sowel met betekenis as met verhoudinge te make het. Sake wat vir mense betekenis het en verhoudings wat waarde toevoeg, maak die proses van herinnering eenvoudiger en waardevoller. Herinnering (anamnese) beïnvloed verder mense se siening van tyd. Dit waaraan gedink word, is betekenisvol vir die hede en dien as 'n stimulus vir toekomstige optrede.

\section{Praktykteoretiese perspektiewe op rekognisie

Interaksie tussen die analiserende en die
normatiewe aspekte - die belang hiervan
vir die liturgie

Die volgende aspekte het vanuit bogenoemde navorsing geblyk, naamlik:

- Onnadenkendheid is 'n gevaar tydens die deelname aan die liturgie. Begrip vir die proses van rekognisie (herinnering) hou rekening met die deelnemers se betrokkenheid by die liturgie. Rekognisie het' $n$ vormende uitwerking op deelnemers aan die erediens. Dit bring 'n dieper ontologiese bewuswording voort.

- In die deelname aan die liturgie onthou deelnemers die bekende aspekte van die verlede as betekenisvol vir die hede en hierdie herinnering dien as stimulus vir toekomstige optrede en verwagting.

- Inligting wat deur middel van sintuie versamel word, word aan die hand van skemas georganiseer. Mense se vorige leerervarings wat in skemas gegiet is, vorm die struktuur of raamwerk waarbinne nuwe inligting ten opsigte van eredienste aangeleer sal word. Hierdie aspek raak die verloop van die hele erediens, alhoewel dit in dié artikel beperk word tot twee momente van die eredienste.

- Die begrip anamnese behels dat gelowiges sal begryp dat die herinnering aan God self op teleologiese wyse as die dieper realiteit ervaar sal word. Anamnese (herinnering) is dinamies en verhoudingmatig met 'n visie daarop dat herinnering in die hede 'n verskil aan die lewens van mense kan maak.

Bogenoemde aspekte ten opsigte van rekognisie, kulmineer in die volgende begrippe, naamlik: betekenis, vertroudheid, vorming, verwagting, dinamiek en verhouding. Die herinnering aan betekenisvolle elemente vorm deelnemers aan erediens wat vertroud is hiermee sodanig dat dit in verhoudings kulmineer. Ietwat anders geformuleer, behels rekognisie tydens die erediens dat dit waarmee mense vertroud is, diepgaande troos bied (teleologies). Nuwe betekenis en nuwe begrip gedy binne die raamwerk van die rekognisie van God se teenwoordigheid en van gesonde verhoudings. Liturgie openbaar daarom 'n vormende krag op die 
lewenswerklikheid. Herinneringe aan die verlede (gister) is leeg en blind indien hulle die hede nie verryk en die toekoms raaksien nie.

\section{Rekognisie (herinnering) en die werklike teenwoordigheid van Christus in die erediens}

Pecklers (2003:25) het aangetoon dat die begrippe erediens en liturgie op direkte wyse met die begrip anamnese (herinnering) te make het. Rekognisie (herinnering) bring 'n gerigtheid van die erediens na vore waarin Christus in die ontmoeting as lewende werklikheid herken word. Die herinnering aan Christus behels 'n herbelewing en 'n bewustheid van die teenwoordigheid ('der Vergegenwärtigung') van die opgestane en verheerlikte Christus wat al die elemente van die liturgie beheers (Atkins 2004:64). In dié opsig behoort liturgie altyd rekening te hou met 'n pneumatologiese vertrekpunt. Trimp (1983:90) het die werking van die Gees in hierdie opsig beskryf as die realiteit dat die Gees op 'n dieptevlak in mense se lewens werk om die dieptes van God tydens die erediens te probeer deurgrond. Rekognisie (herinnering) sou moontlik tot 'n blote verstandsaktiwiteit gereduseer word indien hierdie diepgang van die werking van die Gees nie verreken word nie. Die verlede word deur middel van herinnering in die hede geaktualiseer met die besef dat alles wat Christus bewerkstellig het, nou 'n lewende werklikheid is. Herinnering (rekognisie) aan die teenwoordigheid van die lewende Christus is die kragtige anker aan 'n lewensverwagting, naamlik die finale koms van Christus. Die geheim van die erediens is opgesluit in die rekognisie (herinnering) aan Christus (Wepener 2009:191).

Trimp (1983:109) het jare gelede die betekenis van herinnering beskryf as om daadwerklik oor iets of iemand bekommerd en besorg wees. Sodoende het bogenoemde outeur aangetoon dat nie alleen die verlede en die feite van die verlede van belang is nie, maar dat die proses van rekognisie (herinnering) juis vanuit die verlede elemente oproep wat aktueel is vir die hede om sodoende 'n gefokusde toekomsverwagting te kan hê (Trimp 1983:109). Tussen die blote onthou van Christus se werk en die herinnering aan Christus self wat teenwoordig is tydens die erediens, bestaan 'n groot verskil (Burger 2009:22). Juis omdat deelnemers aan die erediens oortuig is van Christus se teenwoordigheid, dien rekognisie (herinnering) elke keer weer as identifisering en oriëntasie ten opsigte van wat tydens die erediens moet geskied.

In dié artikel is aangetoon dat persone se vertroudheid met die erediens, asook hulle vorige ervarings van die ontmoeting met God bepalend is vir die gemak waarmee herinnering geskied. Deelnemers se vertroudheid en die bekendheid van hul verhouding met God en met mekaar is sodoende belangrike faktore vir die gemak waarmee Christus in die hede onthou word (Atkins 2004:64). Burger (2009:24) toon aan dat die erediens die geleentheid is waarheen gelowiges kom methul aanvegtinge en hulle sodoende hul afhanklikheid kan besef. Tog kom almal na die erediens met 'n eie konteks, asook 'n eie verhaal betreffende hul verhouding met God en met mekaar. Die voorbereiding ten opsigte van die erediens aan die hand van Christus se teenwoordigheid is bepalend vir die rekognisie van die diepgang van die liturgie. Die breër konteks van die erediens wat die deelnemers se verhouding tot God en tot mekaar insluit, is bepalend vir die identifisering (rekognisie) van sinvolle eredienste, asook eredienste wat invloed in die liturgie van die lewe uitoefen. Die proses van rekognisie beïnvloed daarom die sinvolheid van eredienste, asook die deelnemers se verstaan hiervan. Toegepas op die liturgie wil dit voorkom asof die aspekte van persoonlike geloofsgroei, asook die groei in onderlinge verhoudinge tussen deelnemers aan die erediens óf belemmerend kan wees vir rekognisie óf dit andersyds kan bevorder.

\section{Die belangrikheid van die begin van die erediens vir die gang van die erediens}

De Klerk (2006:48) het die volgende hoofmomente in die dinamiese gang van die erediens onderskei, naamlik: die ontmoetingoomblikke (introïtus), die verootmoediging- en versoeningoomblikke, die woordfase en die antwoordfase. In dié onderafdeling word by die eerste twee momente in die dinamiese gang van die erediens stilgestaan, naamlik die ontmoetingdiens, asook die verootmoediging- en versoeningdiens. Die doel hiervan is om aan te toon dat die proses van rekognisie bepalend is vir die sinvolle deelname aan al die elemente van die liturgie. Gebeure wat vanuit die staanspoor van die erediens in terme van herinnering (rekognisie) plaasvind, is wel bepalend vir die deelname aan ander liturgiese elemente soos die Skriflesing, die prediking, gemeentesang, die gebede, die liefdesdiens, asook die wegstuurseën. Laasgenoemde aspekte en hoedanig die proses van rekognisie hierin 'n rol speel, behoort in verdere navorsing aandag te geniet.

\section{Die ontmoetingdiens}

Die gereformeerde erediens begin met die votum as 'n afhanklikheidsverklaring (Van der Merwe 2009:173; De Klerk 2006:49, asook Vos \& Pieterse 1997:205). Juis omdat die erediens 'n ontmoeting tussen God en sy kinders is, behoort die ontmoeting op gepaste wyse te begin met die besef van afhanklikheid en die verbintenis tot toewyding. Dit is daarom gepas om met 'n woord van God of 'n belofte van Hom die erediens te begin en sodoende word deelnemers se herinnering (rekognisie) van die aanvang van die erediens af op God gerig. Deelnemers word onder die indruk gebring dat alles wat verder gaan geskied, juis in die teenwoordigheid van God sal geskied. Die perspektief van rekognisie bring mee dat deelnemers aan die erediens reeds met die aanvang van die erediens (votum en seëngroet) onder die indruk kom van die betekenisvolheid van die erediens (Müller 1990:59). Rekognisie word nadelig beïnvloed indien die elemente van die votum en die seëngroet op formalistiese wyse en as onnadenkende ritueel deur die voorganger gehanteer word. Die herkenning (rekognisie) dat hierdie seën in die Naam van God gedoen word, is so belangrik dat dit selfs met 'n simboliese handgebaar bedien word (visueel en sintuiglik). Deelnemers aan die erediens is egter in vorige ontmoetings, wat nou reeds in skemas gevorm is, gereeld blootgestel aan hierdie elemente en is vertroud met die woorde, asook die gebaar van uitgestrekte hande. Die uitdaging is steeds of 
die betekenis hiervan elke keer weer deur almal opnuut verstaan word. Dit vereis dat die liturg hierdie element betekenisvol sal verrig en kommunikeer sodat gelowiges dit elke keer weer as nuut en dinamies sal ervaar.

Die herinnering deur middel van die votum, asook die seëngroet, behoort tot deelnemers aan die erediens sodanig te spreek dat dit 'n organiese behoefte sal wees om deur middel van lofsang blyke te gee dat hulle God se woorde ter harte neem en dat hulle nou in vrymoedigheid kan sing en verder mag deelneem aan die ontmoeting met God. Hierdie blydskap geskied binne-in die ruimte van 'n herinnering aan identiteit by wyse van die belydenis van geloof ('n element wat liturgies en kommunikatief ook tydens die erediens op ander plekke kan funksioneer). Wanneer gelowiges hul geloof bely, is dit 'n herinnering aan wie God vir gelowiges is. Dit dien verder as 'n handeling waarin gelowiges besef dat hulle aan ' $n$ groter gemeenskap van belydende gelowiges behoort (Atkins 2004:35). Sodoende kom deelnemers deur die rekognisie van die geloofsbelydenis tot ' $n$ identifisering of ' $n$ assosiasie met diegene wat dieselfde as hulle bely. Hierdie aspek kan moontlik beskryf word as die kollektiewe herinnering aan 'n geloofsgemeenskap se identiteit, die heilige, algemene Christelike kerk (Atkins 2004:36). Om sinvol te kan deelneem aan die erediens is dit noodsaaklik dat deelnemers hulle verbintenis met God en met ander gelowiges sal begryp en verbaliseer. Daarom bied die handeling van geloofsbelydenis elke keer die unieke geleentheid om te onthou dat deelnemers deur die geloof aan God behoort en aan ander gelowiges verbind is. Deur die bekende woorde van die geloofsbelydenis word deelnemers in staat gestel om die verlede makliker en op dinamiese wyse in die hede te onthou. Hierdie element roep die herinnering op dat deelnemers aan God en aan ander gelowiges (vgl. liggaammetafoor) verbind is.

Sodoende skep die ontmoetingsdiens nuwe herinneringe aan 'n verhouding met God en word bestaande herinneringe verder versterk (Atkins 2004:142). Dié moment in die ontmoetingsdiens is bepalend vir alles wat verder tydens die erediens sal geskied. Die vreugde van herinnering aan die verbondenheid (identiteit) van die deelnemers is veronderstel om alle liturgiese handelinge wat hierop volg, te verryk. Sodoende besef deelnemers dat God hulle graag wil ontmoet en dat hulle hierdie ontmoeting ervaar saam met ander gelowiges aan wie hulle verbonde voel. Die identifisering van die waarde van dié liturgiese moment bevorder die vermoë van deelnemers aan die liturgie om op toepaslike optrede te besluit. Die kommunikasie en aankondiging van dié element vereis kreatiwiteit sodat nie alleen woorde herroep word nie, maar die betekenis hiervan: naamlik God is teenwoordig.

\section{Die verootmoediging- en versoeningdiens}

Indien die besef (rekognisie) van die teenwoordigheid van God tydens die ontmoeting van die erediens ontbreek, sal die besef van die volmaaktheid van God na alle waarskynlikheid hierdeur geraak word (De Klerk 2006:49). Die rekognisie van die teenwoordige God se volmaaktheid en deelnemers se herinnering aan hulle eie onwaardigheid, word liturgies vergestalt in die belydenis van verootmoediging en versoening. Die herinnering aan eie onwaardigheid te midde van die elemente van verootmoediging en versoening bring deelnemers aan die erediens as dankbaar voor die aangesig van die Here. In hierdie opsig gaan rekognisie in uitkringende sirkels te werk. In die kern staan die besef van God se teenwoordigheid. Die eerste konsentriese sirkel is die herinnering (herkenning) aan eie onmag. Hiermee is elke deelnemer aan die erediens vertroud. Hieruit spruit die herinnering (identifisering) voort van genade en van God se belofte van versoening. Die wyse waarop deelnemers voorheen hiermee vertroud geword het, speel 'n belangrike rol in die gemak waarop herinneringe opgeroep word. Liturgies bestaan daar die slaggat, naamlik om sonde, verootmoediging en versoening sodanig te hanteer dat die een aspek ten koste van die ander funksioneer. Die drie aspekte hierbo genoem, behels dat die mens se vergeetagtigheid weens die sonde juis God se herinnering aan sy kinders noodsaaklik gemaak het (Atkins 2004:42). Liturgies gesproke bied hierdie moment die kragtige potensiaal om Christus self in herinnering te roep. Daarom het liturgie daarmee te make dat daar elke keer weer tydens die erediens nuwe perspektiewe na vore gebring word, selfs langs die weg van wat moontlik bekende elemente van die erediens kan wees. Die herinnering (rekognisie) aan Christus bring egter onvermydelik die herinnering aan talle emosies, asook die mens se eie vergeetagtigheid voort. Langs die weg van herinnering aan die onverdiende genade in Christus geskied die identifisering van 'n nuwe perspektief op die genade van versoening. Indien hierdie moment van die verootmoediging- en versoeningdiens sodanig ingerig word dat Christus self onthou word, kan dit daartoe meewerk dat deelnemers opnuut weer voor hul eie verhouding met Christus geplaas word. Sodoende behoort selfs die wyse waarop hierdie elemente van die verootmoediging- en versoeningdiens gekommunikeer word, deelnemers aan die erediens bemagtig om die betekenis van God se teenwoordigheid in hul lewens te begryp.

Verootmoediging en versoening bring daarom noodwendig sekere geheuefunksies na vore (Vos \& Pieterse 1997:229). Die herinnering aan sonde bring die herinnering aan die troos van versoening in Christus voort. Die dinamika van die herinnering aan eie onmag en aan troos bring 'n buitenste sirkel van rekognisie voort, naamlik van 'n nuwe verbintenis. Die groter sirkel van rekognisie het te make daarmee dat dankbaarheid volgens die maatstaf van God se Woord, voortaan voorop sal staan. Die verootmoediging- en versoeningdiens bereik sodoende 'n diepgang indien nuwe herinneringe oor elke deelnemer se verhouding met God geskep word en elke deelnemer dié moment van die erediens as nuut en vars ervaar (Atkins 2004:143). Indien hierdie moment tydens die erediens geleentheid bied aan die deelnemers om na te dink oor hulle eie sonde, asook die verlossing, kan dit gunstig wees in die skep van 'n nuwe perspektief in 'n lewenswyse wat deur versoening gekenmerk word (Atkins 2004:145). Daarom is dit belangrik dat die herinnering aan die vreugde en dankbaarheid oor die versoening van sondes as die ruimte dien waarbinne die res 
van die liturgie verrig sal word. Herinneringe aan die bekende aspekte skep die geleentheid en habitus vir nuwe herinneringe. Hierdie moment van die erediens sal helaas te kort skiet en ook die res van die erediens skaad indien die rekognisie as identifiseringsmeganisme van hoop nie hierdeur voortgebring word nie. Langs die weg van hierdie moment moet die verwagting juis ontstaan om God se Woord aan te hoor en met ' $n$ nuwe verbintenis hierop te antwoord.

\section{Slot}

In dié artikel is aangetoon dat rekognisie (herinnering) die funksie het van die identifisering van betekenis, asook die werking wat integrasie het. Elke liturgiese element is betekenisvol en vereis dat deelnemers aan die erediens op 'n vars en kreatiewe wyse aan gebeure herinner moet word. In hierdie opsig dien rekognisie om die vinger te plaas op die betekenis van liturgiese momente en elemente. Andersyds verrig rekognisie (herinnering) die rol van integrasie tussen die tydsvorme van gister, vandag en die toekoms. Herinnering dien verder om die integrasie van die betekenis van die erediens met die betekenis van die erediens van die lewe te versterk. Herinneringe tydens die erediens is funksioneel daarin om nuwe herinneringe te skep en om performatief van aard te wees. Liturgie raak mense in die kern van hul bestaan. Sonder herinneringe sukkel mense om sinvol en liturgies te onthou.

\section{Erkennings \\ Mededingende belange}

Die outeur verklaar hiermee dat hy geen finansiële of persoonlike verbintenis het met enige party wat hom voordelig of nadelig kon beïnvloed het in die skryf van hierdie artikel nie.

\section{Literatuurverwysings}

Atkins, P., 2004, Memory and liturgy. The place of memory in the composition and practice of liturgy, Ashgate, London.

Baron, R.A. \& Byrne, D., 1994, Social Psychology, Allyn \& Bacon, Boston, MA.

Berger, T. \& Spinks, B.D., 2009, The Spirit in worship and worship in the Spirit, Liturgical Press, Minnesota.

Bergh, Z. \& Theron, A., 2006, Psychology in the work context, Oxford University Press, Cape Town.

Bradshaw, P.F., 2009, The rediscovery of the Holy Spirit in modern eucharistic theology and practice, Liturgical Press, Minnesota.

Bria, I., 2006, The liturgy after the liturgy, WCC Publications, Geneva.

Bruce, F.F., 1990, 'The epistle to the Hebrews', in The new international commentary of the New Testament, Eerdmans, Grand Rapids, MI.

Burger, C.W., 2009, 'Ontdek die belang van die erediens', in C. Burger, F. Wessels, S. Joubert, D. Smit, \& M. Barnard, (eds.), Ontdekkings in die erediens, bl. 15-31, Lux Verbi, Wellington.

Cartledge, M.J., 2003, Practical theology: Charismatic and empirical perspectives, Paternoster, London.

Chambliss, R., 1989, Social thought, Irvington Publishers, New York.

Ciampa, R.E. \& Rosner, B.S., 2010, 'The first letter to the Corinthians' (in The pillar New Testament commentary, Eerdmans, Grand Rapids, MI.

Cilliers, J., 2004, The living voice of the Gospel. Revisiting the basic principles of preaching, Sun Press, Stellenbosch.

De Klerk, B.J., 2006, 'Wisselwerking tussen liturgie en kultuur in Suid-Afrikaanse konteks: Enkele vertrekpunte', Praktiese Teologie in Suid-Afrika, 16(2), 57-75.

Dingemans, G.D.J., 1996, Practical theology in the academy: A contemporary overview, Kok, Kampen.

Du Toit, A., 2002, Romeine: Hartklop van die evangelie. Beleef God se genade, CTP Drukker, Parow.

Ellingworth, P., 1993, 'Commentary on Hebrews', in New international Greek Testament commentary, Eerdmans, Grand Rapids, MI.
Evans, L.H., 1985, 'Hebrews', in The communicator's commentary, Macmillan, Washington. Eysenck, M.W. \& Keane, M.T., 2010, Cognitive psychology, Psychology Press, New York.

Fiske, S.T., 2004, Social beings: A core motives approach to social psychology, Wiley, Princeton, NJ.

Flanigan, J.M., 1997, 'Hebrews - What the Bible teaches', in Ritchie New Testament commentaries, John Ritchie, Kilmarnock.

Ford, D.F., 2005, The modern theologian. An introduction to Christian theology since 1919, Blackwell, Oxford.

Groenewald, E.P., 1980, Die eerste brief aan die Korintiërs, N.G Kerk Uitgewers, Kaapstad. Haarman, M., 2004, Dies tut zu meinem gedenken, Neukircher Verlag, Kempton.

Horsley, R.A., 1998, 'I Corinthians', in Abingdon New Testament commentaries, Abingdon, Nashville, TN.

Hughes, G., 2003, Worship as meaning: A liturgical theology for late modernity, Cambridge University Press, Cambridge, U.K.

Immink, F.G., 2014, The touch of the sacred. The practice, theology and tradition of Christian worship, Eerdmans, Michigan.

Johnston, W.B., 1994, 'The epistle to the Hebrews', in Calvin's commentaries, Eerdmans, Grand Rapids, MI.

Kistemaker, S.J., 1984, 'Hebrews', in New Testament commentary, Baker Book House, Grand Rapids, MI.

Kruger, F.P., 2015, 'n Praktiese-teologiese ondersoek na prediking en die effek van sosiale kognisie in die handeling van kontekstualisering, in Luce Verbi (in press).

Kruger, F.P., 2016, 'Attitude change through understanding (cognition) of the influence of the persuasive language of liturgy', in HTS (in press).

Kubicki, J.M., 2006, The presence of Christ in the gathered assembly, Continuum, London

Kvanvig, J.I., 2008, 'Epistemology: An anthology', in E. Sosa, J. Kim, J. Fantl \& M. Mcgrath (eds.), Why should inquiring minds want to know? Meno problems and epistemological axiology, pp. 492-507, Blackwell, Singapore.

Long, T.G., 1997, Hebrews. Interpretation. A Bible commentary for teaching and preaching, John Knox, Louisville.

Louw, D., \& Edwards, D., 1998, Psychology. Introduction for students in South Africa, Heinemann, Sandton.

Louw, D.J., 2015, Academic theology: Between sapientia (wisdom) and scientia (science). Theory formation in Practical Theology, University of Stellenbosch, Stellenbosch.

Louw, J.P., \& Nida, E.A., 1993, Greek-English lexicon of the New Testament (I), United Bible Studies, New York.

McShane, A., 1999, I and II Corinthians, Bath Press, Glasgow. (What the Bible teaches: Richie New Testament Commentaries).

Mitchell, H.H., 2008, Celebration and experience in preaching, Abingdon Press, Nashville, TN.

Moore-Keish, M.L., 2008, Do this in remembrance of me. A ritual approach to Reformed eucharistic theology, Eerdmans, Michigan.

Müller, J., 1990, Die erediens as fees, N.G. Kerkboekhandel, Pretoria.

Nullens, P., 2015, Zorgen voor een eigenwijze kudde. Een pastorale ethiek voor een missionaire kerk, Uitgeverij Boekencentrum, Zoetermeer.

Osmer, R., 2008, Practical theology: An introduction, Eerdmans, Grand Rapids, MI.

Schwartz, L., \& De La Rey, C., 2004, Introduction to psychology, University Press, Oxford.

Pakpahan, B.J., 2012, God remembers. Towards a theology of remembrance as a basis of reconciliation in communal conflict, VU University Press, Amsterdam.

Pecklers,K., 2003, Liturgy in a postmodern world, Continuum, London.

Pieterse, H.J.C., 2001, Prediking in 'n konteks van armoede, UNISA, Pretoria.

Routhier, G., 2015, 'Liturgical formation', paper presented at the Societas Liturgica, Quebec, Canada, 11th August.

Smith, J.K.A., 2013, Desiring the Kingdom: Worship, worldview and cultural formation, Baker Academic, Grand Rapids, MI

Stetter, M., 2013, 'Viva Vox Evangelii-reforming preaching', in J., Hermelink \& A. Deeg, (eds.), The transformative dimension of preaching, pp. 376-387, Evangelische Verlaganstalt, Leipzig.

Strawn, B.D. \& Brown, W.S., 2013, 'Liturgical animals: What psychology and neuroscience tell us about formation and worship', Liturgy, 28(4):3-14.

Trimp, C., 1983, De gemeente en haar liturgie, Van den Berg, Kampen.

Van der Merwe, J., 2009, 'Ontdek die bewegings in die erediens', in C. Burger, F. Wessels, S. Joubert, D. Smit, \& M. Barnard, (eds.), Ontdekkings in die erediens, bl. 165-178, Lux Verbi, Wellington.

Venter, P., Symington, J. \& Van Wyk, A., 2007, Augustinus se belydenisse, Lux Verbi, Wellington.

Vos, C., 2009, 'God in 'n kantelende wêreld', in F.G. Immink \& C. Vos, (eds.), Godsbeelde in die liturgie, pp. 297-310, Protea, Pretoria.

Vos, C.J.A., \& Pieterse, H.J.C., 1997, Hoe lieflik is U woning, RGN, Pretoria.

Weiten, W., 1995, Psychology: Themes and variations, Brooks \& Cole, California.

Wepener, C., 2009, 'Ontdek die draaipunte in die geskiedenis van liturgie', in C. Burger, F. Wessels, S. Joubert, D. Smit, \& Barnard, M. (eds.), Ontdekkings in die erediens, Lux Verbi, Wellington.

Wood, S.E. \& Wood, E.G., 1999, The world of psychology, Alyn \& Bacon, London. 